\title{
Seroprevalence of Leptospiral Antibodies among Healthy Municipal Service Workers in Selangor
}

\author{
Suhailah Samsudin, ${ }^{1}$ Siti Norbaya Masri, ${ }^{2}$ Tengku Zetty Maztura Tengku Jamaluddin, ${ }^{2}$ \\ Siti Nor Sakinah Saudi, ${ }^{1}$ Umi Kalsom Md Ariffin, ${ }^{3}$ Fairuz Amran, ${ }^{4}$ and Malina Osman ${ }^{2}$ \\ ${ }^{1}$ Department of Community Health, Faculty of Medicine and Health Sciences, Universiti Putra Malaysia (UPM), \\ 43400 Serdang, Selangor, Malaysia \\ ${ }^{2}$ Department of Medical Microbiology and Parasitology, Faculty of Medicine and Health Sciences, Universiti Putra Malaysia (UPM), \\ 43400 Serdang, Selangor, Malaysia \\ ${ }^{3}$ Department of Urban Services and Health, Ampang Jaya Municipal Council (MPAJ), Jalan Pandan Utama, Taman Pandah Indah, \\ 55100 Ampang, Selangor, Malaysia \\ ${ }^{4}$ Institute of Medical Research, Jalan Pahang, 50588 Kuala Lumpur, Malaysia
}

Correspondence should be addressed to Malina Osman; malinaosman@upm.edu.my

Received 19 August 2014; Accepted 26 December 2014

Academic Editor: Guang-Hui Dong

Copyright (C) 2015 Suhailah Samsudin et al. This is an open access article distributed under the Creative Commons Attribution License, which permits unrestricted use, distribution, and reproduction in any medium, provided the original work is properly cited.

\begin{abstract}
Introduction. Municipal service workers have been found to have an occupational risk of leptospirosis. Study among municipality workers shows high seropositivity of leptospiral antibodies detected among town cleaners and garbage collectors. Objective. Aims of this study were to determine seroprevalence of leptospiral antibodies and distribution of serovars detected in samples among municipal service workers. Methodology. Cross-sectional study involved 89 municipal service workers in Selangor. Blood samples were taken and serological test was done using MAT following standard procedures. Results. Seropositivity of leptospiral antibodies among municipal service workers was $34.8 \%$. Serovars identified were strains of Sarawak, Copenhageni, Hardjobovis, Lai, Bataviae, Patoc, Celledoni, Hardjoprajitno, Tarrasovi, and Pomona. There were 31 workers with positive leptospiral antibodies. All of them were frequently exposed towards leptospirosis. Significant associations have been reported between seropositivity of leptospiral antibodies with job category $(P=0.021)$ and worker's nationality $(P=0.014)$ among municipal service workers. Conclusion. High seropositivity of leptospiral antibodies detected among municipal service workers which was associated with job category and nationality of workers. The significant findings from this study suggest that health education programs and safe work practice should be considered to prevent leptospirosis among municipal service workers in future.
\end{abstract}

\section{Introduction}

Leptospirosis is an infectious disease that affects humans and animals. It is considered as the most widespread reemerging zoonotic disease in the world [1-3]. The high prevalence of leptospirosis in humans is of great public health concern, particularly in tropical and subtropical regions. Recent data have shown that human leptospirosis is an endemic infection in Malaysia [2, 4]. An increasing trend of cases occurs in this country between 2005 and 2009, starting with 263 cases in 2004 and up to 1418 in 2009 [5, 6]. Cases continually rise in
2010 with 1876 cases followed by 2268 cases in 2011 and 3665 cases in 2012 [7, 8].

Human infections may be acquired through occupational, recreational, or environmental exposures [2]. Occupational outdoor job involved direct contact with soil, mud, or water during work putting individuals at risk. Environmental exposure through environmental sanitation and hygiene is a proven factor being responsible for the disease [9]. Positive result of leptospiral antibodies was reported among sanitation workers in Brazil. Majority of them had job exposure towards environmental sanitation concerned with 
water supply, drains and drainage, galleries, sewers, garbage collection, and road sweeping [10].

Rampant urbanization of cities can lead to improper garbage management system in urban areas, creating favourable conditions for animal carriers [11]. The most important animals associated with human leptospirosis are peridomestic rodents which are rats and mice $[12,13]$. This may pose a health risk for leptospirosis as animal reservoir might contaminate environmental waters and soils via their excreta and urine [11].

Ampang Jaya Municipal Council was facing unrelieved problems regarding high number of rat population especially in residential areas. Furthermore, urban rats are prolific breeders with average weight up to one kilogram and may produce up to fifteen rats a year [14]. The council had created a method to control this issue such as rat elimination campaigns in their authority areas. Furthermore, eradication of rats indirectly may prevent spreading of Leptospira which is commonly transmitted by rats. This situation becomes crucial for any work activities which involve environmental sanitation and rat catching campaign. Thus, the council as the employer and local authority has to ensure safe working environment and proper procedures are followed by workers and individuals with high probability of exposure towards leptospirosis. In order to address this issue, the study of seroprevalence of leptospiral antibodies among municipal service workers was performed.

The purpose of this study was to determine seroprevalence of leptospiral antibodies and distribution of Leptospira serovars presented in sample of municipal service workers. Furthermore, the association between seropositivity of leptospiral antibodies with job category and nationality of municipal service workers was also determined in this study.

\section{Materials and Methods}

2.1. Study Design and Population. A cross-sectional study was conducted in December 2012 until May 2013 at Ampang Jaya Municipal Council (MPAJ) which is located in an urban area of Selangor. The study population was healthy municipal service workers with no recent signs and symptoms related to leptospirosis within 2-3 weeks during the period of data collection and working as garbage collector, town cleaner, public worker, and public health assistant in MPAJ. Workers who did not meet these inclusive criteria were excluded from this study. The study used a nonprobability sampling. The total of workers participating in this study was 89 healthy workers, who fulfilled all the inclusive criteria.

2.2. Sample Collection and Serological Test. Respondents were identified from a list provided from the MPAJ Health Office. Informed written consent was obtained from all respondents based on approved study protocol by the Medical Research Ethics Committee, Universiti Putra Malaysia. Blood samples from workers were obtained by using venepuncture technique. Five milliliters of venous blood was drawn by medically trained personnel and collected into sterile blood containers. The blood in plain tube was centrifuged for 10 minutes by using the Powerspin MX centrifuge machine at $3000 \mathrm{rpm}$ (round per minute) to obtain the serum. The serum was kept at $-20^{\circ} \mathrm{C}$ in a freezer until it is further processed $[2,15]$.

The microscopic agglutination test (MAT) was performed to determine the presence of Leptospira antibodies among municipal service workers. The MAT was performed with a panel of 20 live reference serovars, representing 20 serogroups that were used as antigen, as recommended by WHO [16]. Each serum sample was subjected to serial dilution by using phosphate buffered saline (PBS). Then, the microtitre plates were incubated at room temperature in the dark for two (2) hours. Agglutination was determined by slide agglutination method which gives an agglutination of at least $50 \%$ of the leptospires which is considered positive in this study.

Leptospira reference serovars were obtained for local (Malaysian Serovar) and WHO from Institute Medical Research, Malaysia. The serovars used in the MAT were divided into local and WHO. Serovars for local were Melaka, Terengganu, Sarawak, Copenhageni, Hardjobovis, and Lai. Serovar for WHO consists of Australis, Autumnalis, Bataviae, Canicola, Celledoni, Grippotyphosa, Hardjoprajitno, Icterohaemorrhagiae, Javanica, Pyrogenes, Tarrasovi, Djasiman, Patoc, and Pomona.

In this study, we used titre of $1 \geq 50$ as cut-off value because respondents were healthy workers without any symptoms related to leptospirosis. Furthermore, there is no standard cut-off titre in this local geographical area as a baseline in the community [2]. Some studies used cut-off titre of $1 \geq 100$ but there is controversy on the single diagnostic titre as it is dependent on endemicity [17]. In this study, we used titre of 1 $\geq 50$ to avoid probability in underestimation of seroprevalent [2]. Study by Shivakumar and Krishnakumar also used cutoff titre of $1 \geq 50$ on serosurveys in the asymptomatic high risk group [17].

2.3. Statistical Analysis. Data were entered and analyzed by using Statistical Packages for Social Sciences (SPSS) Version 21.0. Analysis was done by using this software at different levels. The level of significance in this study was set up at $P<0.05$. Descriptive analysis was limited to identify sociodemographic characteristics of respondents.

\section{Result}

3.1. Sociodemographic Characteristics. Eighty-nine workers were recruited into the study based on the list of workers provided by the municipal office. The distribution of respondents by gender showed there were $84(94.4 \%)$ male workers and only 5 (5.6\%) female workers. Most of respondents participated in this study were foreigners, $79(88.8 \%)$ and Malaysians, 10 (11.2\%). The distribution of respondents by job category was divided into two parts which were frequently exposed to leptospirosis and infrequently exposed to leptospirosis. Frequently exposed group consists of fiftythree (59.6\%) garbage collectors and twenty-six (29.2\%) town cleaners, while infrequently exposed group consists of 
TABLE 1: Sociodemographic characteristic of municipal service workers.

\begin{tabular}{lcc}
\hline Variable & \multicolumn{2}{c}{ Study group } \\
& $n$ & $(\%)$ \\
\hline Gender & & \\
$\quad$ Male & 84 & 94.4 \\
Female & 5 & 5.6 \\
Nationality & & \\
$\quad$ Malaysian & 10 & 11.2 \\
Foreign & 79 & 88.8 \\
Job category & & \\
Frequently exposed & & \\
$\quad$ Garbage collector & & \\
$\quad$ Town cleaner & 53 & 59.6 \\
Infrequently exposed & 27 & 30.3 \\
$\quad$ Public worker & & \\
$\quad$ Public health assistant & 6 & 3.3 \\
\hline
\end{tabular}

$n=89$, total number of respondent in the study.

TABLE 2: Prevalence of leptospiral antibodies among municipal service workers.

\begin{tabular}{lc}
\hline Variable & $\begin{array}{c}\text { Study group } \\
n=89 \\
n(\%)\end{array}$ \\
\hline Leptospiral antibodies & \\
$\quad$ Positive & $31(34.8)$ \\
$\quad$ Negative & $58(65.2)$ \\
\hline$n=89$. &
\end{tabular}

seven $(7.9 \%)$ public workers and three (3.3\%) public health assistants (Table 1).

3.2. Prevalence of Leptospiral Antibodies. For distribution of seroprevalence of leptospiral antibodies, thirty-one (34.8\%) respondents involved in this study were seropositive and fiftyeight $(65.2 \%)$ respondents were seronegative of leptospiral antibodies (Table 2). The highest seropositivity of leptospiral antibodies was detected among garbage collectors, twentytwo $(41.5 \%)$ workers followed by nine $(33.3 \%)$ town cleaners. All public workers and public health assistants were seronegative of leptospiral antibodies in this study (Table 3).

For local Leptospira serovar, positive samples were identified as serovars Sarawak, Copenhageni, Hardjobovis, and Lai. The highest local serovar was Sarawak (37.0\%) and the lowest serovars present for local serovar were Copenhageni (5.0\%) (Figure 1), while in WHO Leptospira serovar positive samples were serovars Bataviae, Celledoni, Hardjoprajitno, Tarrasovi, Patoc, and Pomona. Mainly serovars present were Bataviae (57.0\%), followed by Patoc (27.0\%), and only $4.0 \%$ was identified in each serovar, Celledoni, Hardjoprajitno, Tarrasovi, and Pomona (Figure 2).

Only eleven of respondents had monoserovar antibody. The highest frequency of serovars was pentaserovars,
TABLE 3: Prevalence of leptospiral antibodies according to job category.

\begin{tabular}{lcc}
\hline \multirow{2}{*}{ Variable } & \multicolumn{2}{c}{ Leptospiral antibodies } \\
& Positive (\%) & Negative (\%) \\
\hline Job category & $22(41.5)$ & $31(58.5)$ \\
Garbage collector & $9(33.3)$ & $18(66.7)$ \\
Town cleaner & $0(0.0)$ & $6(100.0)$ \\
Public worker & $0(0.0)$ & $3(100.0)$ \\
Public health worker & $\mathbf{3 1 ( 3 4 . 8 )}$ & $\mathbf{5 8 ( 6 5 . 2 )}$ \\
Total &
\end{tabular}

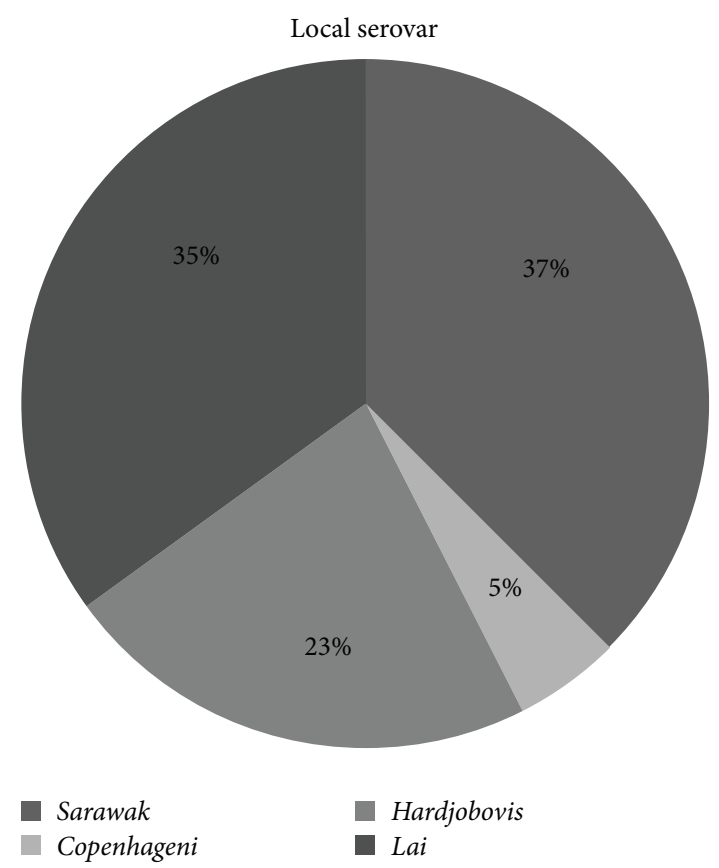

FIgURE 1: Serovar (local) among seropositive municipal service workers.

detected from a Burmese (Myanmar) working as garbage collector in MPAJ (Figure 3). The study found 26 of serovars at titre of $1 \geq 50$ and 17 serovars at titer of $1 \geq 100$ while 12 serovars were found at titer of $1 \geq 200$ and 11 of serovars at $1 \geq 400$ (Table 4 ). In addition, 16 from 31 workers who are positive of leptospiral antibodies had both local and WHO serovars, four workers had positive leptospiral antibodies with more than one local serovar, and one worker had positive four WHO serovars.

3.3. Association between Seropositivity of Leptospiral Antibodies with Job Category and Nationality among Municipal Service Workers. In this study, thirty-one workers $(38.8 \%)$ in the frequently exposed group had positive leptospiral antibodies, while forty-nine (61.3\%) had negative result. All nine respondents who were infrequently exposed towards leptospirosis were negative leptospiral antibodies. There was significant association between seropositivity of leptospiral antibodies and job category of municipal service workers $(P=0.021)$. Furthermore, there was also a significant 


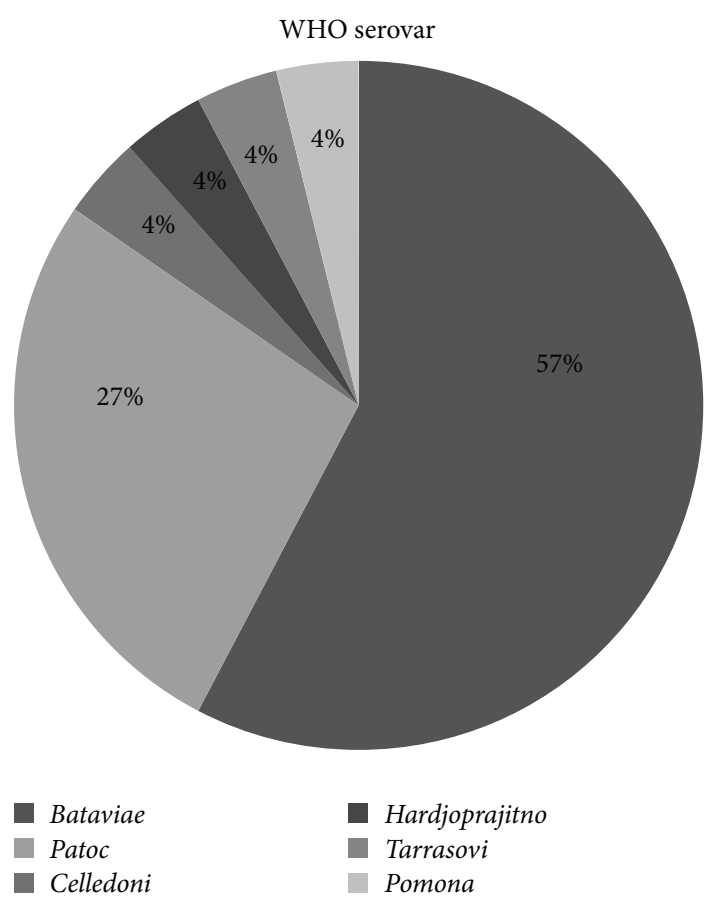

FIGURE 2: Serovar (WHO) among seropositive municipal service workers.

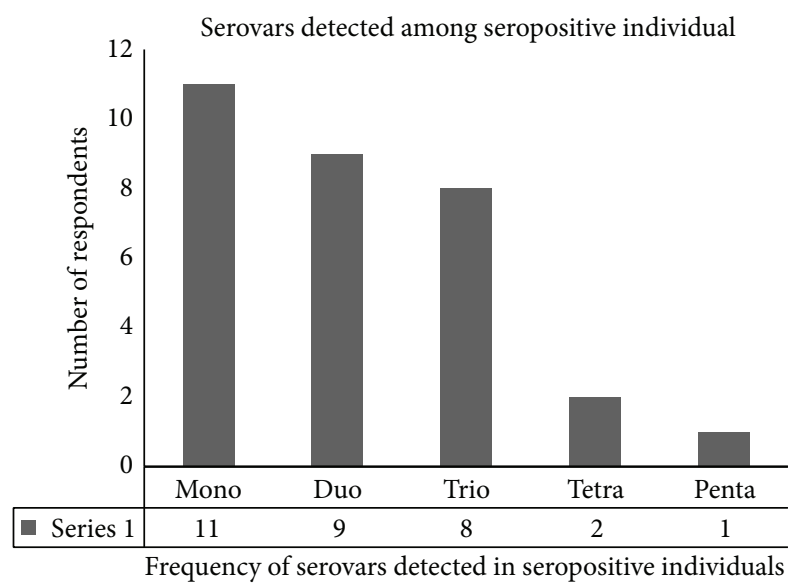

FIGURE 3: Frequency of serovars in seropositive samples.

association between seropositivity of leptospiral antibodies and nationality of municipal service workers $(P=0.014)$ (Table 5).

\section{Discussion}

4.1. Leptospiral Antibodies Status among Municipal Service Workers. Findings in this study showed a high prevalence (34.8\%) of leptospiral antibodies among municipal service workers. All respondents who are involved in this study did not have any signs and symptoms suggestive of Leptospira infection. Asymptomatic infection of leptospirosis is common and has been reported in many studies. In 2012, Nazri et al. [2] reported that there was $24.8 \%$ seroprevalence
TABLE 4: Leptospiral antibody titres of local and WHO serovars.

\begin{tabular}{|c|c|c|c|c|}
\hline \multirow{2}{*}{ Local serovar } & \multicolumn{4}{|c|}{ Titres } \\
\hline & $1: 50$ & $1: 100$ & $1: 200$ & $1: 400$ \\
\hline $\begin{array}{l}\text { Melaka } \\
\text { (IMR LEP 1) }\end{array}$ & 0 & 0 & 0 & 0 \\
\hline $\begin{array}{l}\text { Terengganu } \\
\text { (IMR LEP 115) }\end{array}$ & 0 & 0 & 0 & 0 \\
\hline $\begin{array}{l}\text { Sarawak } \\
\text { (IMR LEP 175) }\end{array}$ & 5 & 3 & 4 & 3 \\
\hline $\begin{array}{l}\text { Copenhageni } \\
(\text { IMR LEP 803/11) }\end{array}$ & 0 & 1 & 0 & 1 \\
\hline $\begin{array}{l}\text { Hardjobovis } \\
\text { (IMR LEP 27) }\end{array}$ & 0 & 2 & 3 & 4 \\
\hline $\begin{array}{l}\text { Lai } \\
\text { (IMR LEP 22) }\end{array}$ & 11 & 3 & 0 & 0 \\
\hline \multicolumn{5}{|l|}{ WHO serovar } \\
\hline Australis & 0 & 0 & 0 & 0 \\
\hline Autumnalis & 0 & 0 & 0 & 0 \\
\hline Bataviae & 6 & 4 & 3 & 2 \\
\hline Canicola & 0 & 0 & 0 & 0 \\
\hline Celledoni & 1 & 0 & 0 & 0 \\
\hline Grippotyphosa & 0 & 0 & 0 & 0 \\
\hline Hardjoprajitno & 1 & 0 & 0 & 0 \\
\hline Icterohaemorrhage & 0 & 0 & 0 & 0 \\
\hline Javanica & 0 & 0 & 0 & 0 \\
\hline Pyrogenes & 0 & 0 & 0 & 0 \\
\hline Tarrasovi & 0 & 1 & 0 & 0 \\
\hline Djasiman & 0 & 0 & 0 & 0 \\
\hline Patoc & 1 & 3 & 2 & 1 \\
\hline Pomona & 1 & 0 & 0 & 0 \\
\hline Total & 26 & 17 & 12 & 11 \\
\hline
\end{tabular}

TABLE 5: Association between seropositivity of leptospiral antibodies with job category and nationality among municipal service workers.

\begin{tabular}{lccc}
\hline Variable & \multicolumn{2}{c}{ Leptospiral antibodies } & P \\
& Positive (\%) & Negative (\%) & \\
\hline Job category & $31(38.8)$ & $49(61.2)$ & \\
$\quad \begin{array}{l}\text { Frequently exposed to } \\
\text { leptospirosis infection }\end{array}$ & & & $0.021^{\mathrm{a}}$ \\
$\quad \begin{array}{l}\text { Infrequently exposed to } \\
\text { leptospirosis infection }\end{array}$ & $0(0.0)$ & $9(100.0)$ & \\
$\begin{array}{l}\text { Nationality } \\
\quad \text { Malaysian }\end{array}$ & $0(0.0)$ & $10(0.0)$ & $0.014^{\mathrm{a}}$ \\
$\quad$ Foreign & $31(39.2)$ & $48(60.8)$ & \\
Total & $\mathbf{3 1}$ & $\mathbf{5 8}$ & \\
\hline $\begin{array}{l}n=89 . \\
{ }^{\mathrm{a}} \text { Chi-square test. }\end{array}$ & & & \\
& & &
\end{tabular}

of leptospirosis among town service workers in Kelantan. Another local study in north-eastern Malaysia reported 31.0\% of confirmed leptospirosis case at titre of $1 \geq 400$ by MAT 
[18]. Even though both previous studies $[2,18]$ were from the same locality, seroprevalence of leptospiral antibodies showed distinct values as cut-off value for titre used was different. As our study showed higher seroprevalence (34.8\%) compared with previous study $(24.8 \%)$ in similar study population in Kelantan probably due to different locality of study, Ratnam et al. [19] showed sanitation workers in urban areas had the highest risk of leptospiral infection with seroprevalence recording $32.9 \%$.

Ampang Jaya is an urban area with high population density. Rapid development of infrastructure such as construction of new houses and commercial buildings makes the area more complex and crowded. High positivity in seroprevalence of leptospiral antibodies in this study probably related to urbanization and improper waste disposal. Swapna et al. [13] reported similar association between urbanization and seroprevalence of leptospirosis. In Calicut, India, the rapid urbanization and man-made ecoenvironmental disturbances may have contributed to water logging condition which increase in leptospirosis cases in this region [13].

Moreover, there is an abundance of food premises such as stalls, restaurants, and markets to cater for its dense population resulting in more conducive environments and solid waste deposited in Ampang Jaya, thus contributing to the increasing of rat population in Ampang Jaya these past years. Workers who are involved in sanitation activity such as garbage collectors and town cleaners have a higher tendency to be exposed to leptospiral infection.

\subsection{Distribution of Local and WHO Serovar among Municipal} Service Workers. In this study, the most common serovar detected among local serovar was Sarawak (37.0\%) while WHO serovar was Bataviae (57.0\%). Similarly, Nazri et al. [2] reported that serovar Bataviae was the predominant pathogenic serovars in his study in Kelantan. In addition to this, Swapna et al. [13] also verified serovar Bataviae as one of the predominant serovars among workers in North Kerala, India. Similar findings were also documented by Van et al. [20] in the Mekong Delta, Vietnam, which documented fifty-seven cases of Bataviae among seropositive subjects. Other than that, there was presence of serovar Patoc in seven respondents. The study by Nazri et al. [2] also found that serovar Patoc was the most common serovar identified among town service workers with twenty-nine serovar detected.

\subsection{Distribution of Serovar Frequencies among Seropositive} Municipal Service Workers. This study shows a frequency of serovars detected among seropositive respondents. Majority of respondents had monoserovar leptospiral antibody. Throughout the study, we have identified pentaserovars (Sarawak, Hardjobovis, Lai, Bataviae, and Patoc) from a Burmese (Myanmar) garbage collector who had been working in Malaysia for the past 10 years.

Besides, there were four respondents from Myanmar who had double serovars detected with titre of $1 \geq 400$ during this study. The study among environmental sanitation workers in the southern region of Brazil reported that $10.4 \%$ was positive to one or more serovars [10]. Higher frequency of serovars detected in this population is probably due to their routine jobs and poor hygiene practices. This finding indicates that workers involved in waste management such as garbage collectors have higher risk of getting leptospirosis. From our observations during sample collection, personal protective equipment usage was inadequate among the garbage collectors. None of the garbage collectors wore gloves while working and only few of them wore long sleeve shirts and boots while working. These might contribute to the high exposure towards Leptospira hence contributing to the high seroprevalence and frequency of serovars among this population.

\section{Conclusion}

This study had determined a high seroprevalence (34.8\%) of leptospiral antibodies among municipal service workers. Seropositivity among municipal service workers was associated with job and nationality. These findings show that municipal service workers have occupational risk of contracting leptospirosis infection. This may be due to the daily exposure in managing solid waste which may be contaminated with Leptospira. In order to handle this issue, proper health program and training in using personal protective equipment should be initiated among municipal service workers to reduce risk of infection.

There were two predominant serovars detected among seropositive municipal service workers which are Sarawak and Bataviae. Many other studies on leptospirosis included study on animal reservoirs. However, this study did not include leptospirosis among animal reservoirs. Thus, we could not conclude if WHO serovar or local serovar was contracted during the course of work. Hence, we were unable to compare the serovar frequency between humans and reservoirs.

In this study, one of the seropositive respondents had five different serovars detected in his sample, probably due to frequent exposure and poor hygiene practices. The findings indicate that workers involved in waste management such as garbage collectors have higher risk of getting leptospirosis. The result shows an alarming sign of public health problem to initiate leptospirosis control program. Health education to the public regarding leptospirosis should be done, so that the public can be more aware of the risk of infection. Collaborative approach by local authorities, government, and private agencies should be done to reduce favourable environment for the rats. Proper approach should be planned towards this type of occupation in avoidance of leptospirosis in future.

\section{Study Limitation}

The study was performed in a single population, among municipal service workers in Ampang Jaya; future findings may not be generalized to other populations. The study was a cross-sectional study; therefore, it could only determine the antibody level at the present time of blood sampling. It could 
not determine the temporal relationship between leptospiral infection and the leptospiral antibodies. There was a sampling bias in this study. Sampling bias can be minimized through randomly chosen respondent from a listing of workers.

\section{Ethical Approval}

Ethical approval had been obtained from Medical Research Ethics Committee, Universiti Putra Malaysia (JKEUPM), and permission from Ampang Jaya Municipal Council (MPAJ) prior to the commencement of this study.

\section{Conflict of Interests}

The authors declare that there is no conflict of interests regarding the publication of this paper.

\section{Acknowledgments}

The authors would like to express their deepest gratitude and thanks to Ampang Jaya Municipal Council (MPAJ) and their workers for their support and contribution in this study. They personally thank Dr. Saliza Mohd Elias for guidance through the study and staff from the Department of Medical Microbiology and Parasitology, Faculty of Medicine and Health Sciences, UPM, for their great assistance.

\section{References}

[1] M. Sapian, M. T. Khairi, S. H. How et al., "Outbreak of melioidosis and leptospirosis co-infection following a rescue operation," Medical Journal of Malaysia, vol. 67, no. 3, pp. 293-297, 2012.

[2] S. M. Nazri, S. M. Rahim, N. Y. Azwany et al., "Seroprevalence of leptospirosis among town service workers in Northeastern state of Malaysia," International Journal of Collaborative Research on Internal Medicine and Public Health, vol. 4, no. 4, pp. 395-403, 2012.

[3] A. P. Sugunan, P. Vijayachari, S. Sharma et al., "Risk factors associated with leptospirosis during an outbreak in Middle Andaman, India," The Indian Journal of Medical Research, vol. 130, no. 1, pp. 67-73, 2009.

[4] I. M. El Jalii and A. R. Bahaman, A Review of Human Leptospirosis in Malaysia, 2006.

[5] MOH, Guidelines for the Diagnosis, Management, Prevention and Control of Leptospirosis in Malaysia, Disease Control Division Department of Public Health, Ministry of Health Malaysia, Putrajaya, Malaysia, 1st edition, 2011.

[6] J. K. Lim, V. A. Murugaiyah, A. Ramli et al., A Case Study: Leptospirosis in Malaysia, 2011.

[7] S. Khairani-Bejo, Leptospirosis and Environment. Prosiding Kolokium Leptospirosis Pendekatan 'One Health' Dalam Pengawalan Leptospirosis, PICC, Putrajaya, Malaysia, 2012.

[8] E. Fernandez, "Keep clean: Health Ministry advises against patronizing dirty outlets," 2013, http://www2.nst.com.my/ nation/general/2-775-leptospirosis-cases-23-deaths-this-year1.340149 .

[9] R. Kamath, S. Swain, S. Pattanshetty, and N. S. Nair, "Studying risk factors associated with human leptospirosis," Journal of Global Infectious Diseases, vol. 6, no. 1, pp. 3-9, 2014.
[10] L. P. de Almeida, L. F. Martins, C. S. Brod, and P. M. Germano, "Seroepidemiologic survey of leptospirosis among environmental sanitation workers in an urban locality in the Southern region of Brazil," Revista de Saude Publica, vol. 28, no. 1, pp. 76-81, 1994.

[11] D. Benacer, P. Y. Who, S. N. M. Zain, F. Amran, and K. L. Thong, "Pathogenic and saprophytic Leptospira species in water and soils from selected urban sites in peninsular Malaysia," Microbes and Environments, vol. 28, no. 1, pp. 135-140, 2013.

[12] A. R. M. Mohan and D. D. Chadee, "Knowledge, attitudes and practices of Trinidadian households regarding leptospirosis and related matters," International Health, vol. 3, no. 2, pp. 131-137, 2011.

[13] R. N. Swapna, U. Tuteja, L. Nair, and J. Sudarsana, "Seroprevalence of leptospirosis in high risk groups in Calicut, North Kerala, India," Indian Journal of Medical Microbiology, vol. 24, no. 4, pp. 349-352, 2006.

[14] R. A. Ismail, Bukan habuan "ternak" tikus, 2011, http://www .hmetro.com.my/myMetro/articles/Bukanhabuan__8216_ternak__8217_tikus/Article/index_html.

[15] WHO, Human Leptospirosis: Guidance for Diagnosis, Surveillance and Control, 2003, http://whqlibdoc.who.int/hq/2003/ WHO_CDS_CSR_EPH_2002.23.pdf.

[16] WHO, Leptospirosis: Laboratory Manual, World Health Organization, 2007.

[17] S. Shivakumar and B. Krishnakumar, "Diagnosis of Leptospirosis-role of MAT," Journal of Association of Physicians of India, vol. 54, pp. 338-339, 2006.

[18] A. A. Noor Rafizah, B. D. Aziah, Y. N. Azwany et al., "Leptospirosis in Northeastern Malaysia: misdiagnosed or coinfection?" International Journal of Collaborative Research on Internal Medicine \& Public Health, vol. 4, no. 7, p. 1419, 2012.

[19] S. Ratnam, C. O. R. Everard, J. C. Alex, B. Suresh, and P. Thangaraju, "Prevalence of leptospiral agglutinins among conservancy workers in Madras City, India," Journal of Tropical Medicine and Hygiene, vol. 96, no. 1, pp. 41-45, 1993.

[20] C. T. B. Van, N. T. T. Thuy, N. H. San, T. T. Hien, G. Baranton, and P. Perolat, "Human leptospirosis in the Mekong delta, Viet Nam," Transactions of the Royal Society of Tropical Medicine and Hygiene, vol. 92, no. 6, pp. 625-628, 1998. 


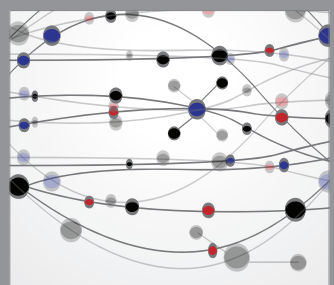

The Scientific World Journal
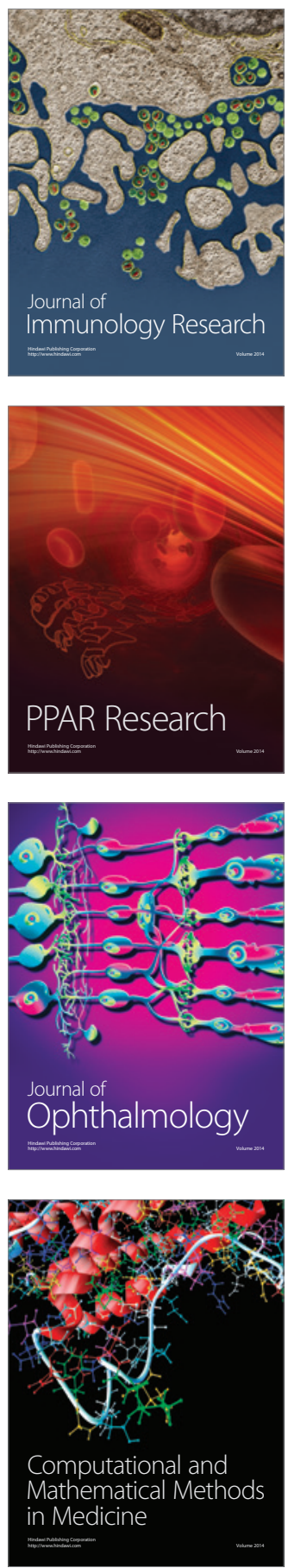

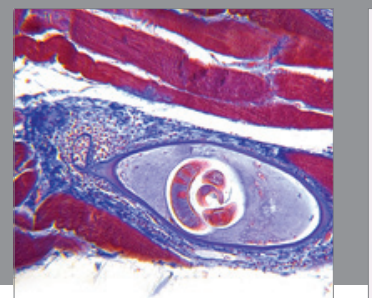

Gastroenterology

Research and Practice
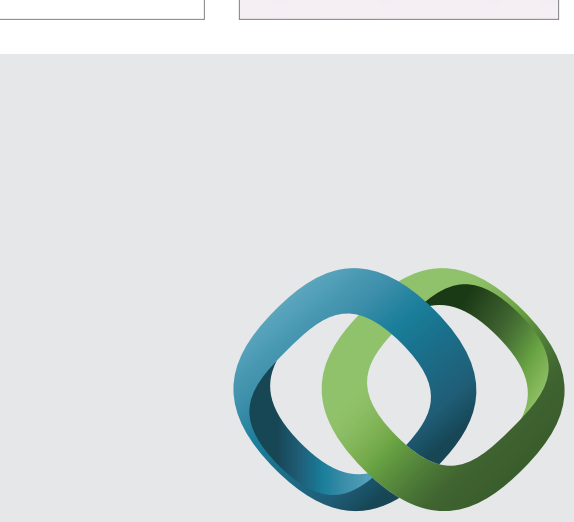

\section{Hindawi}

Submit your manuscripts at

http://www.hindawi.com
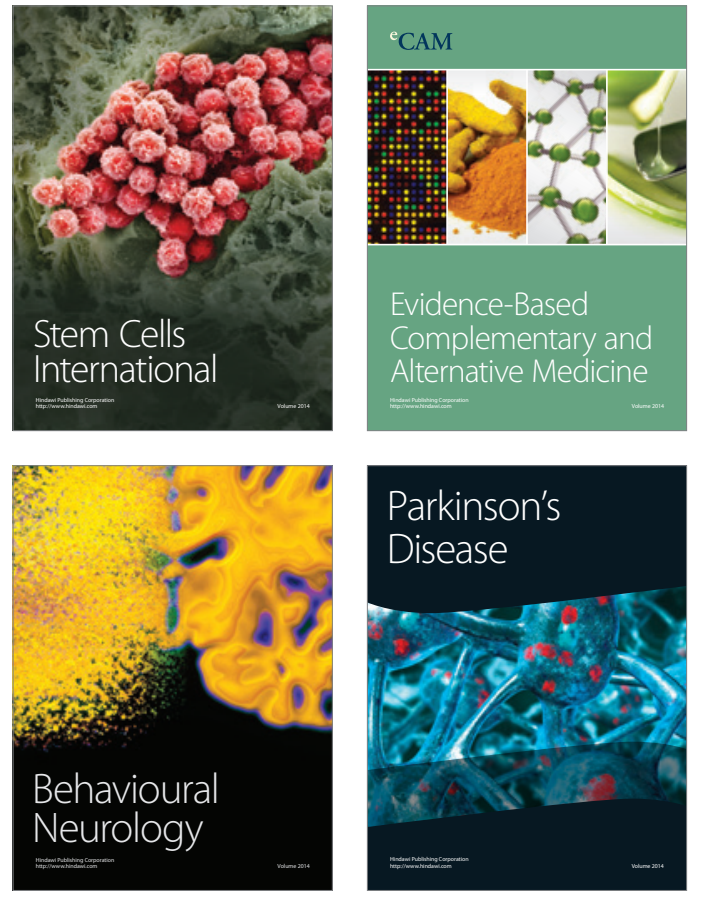
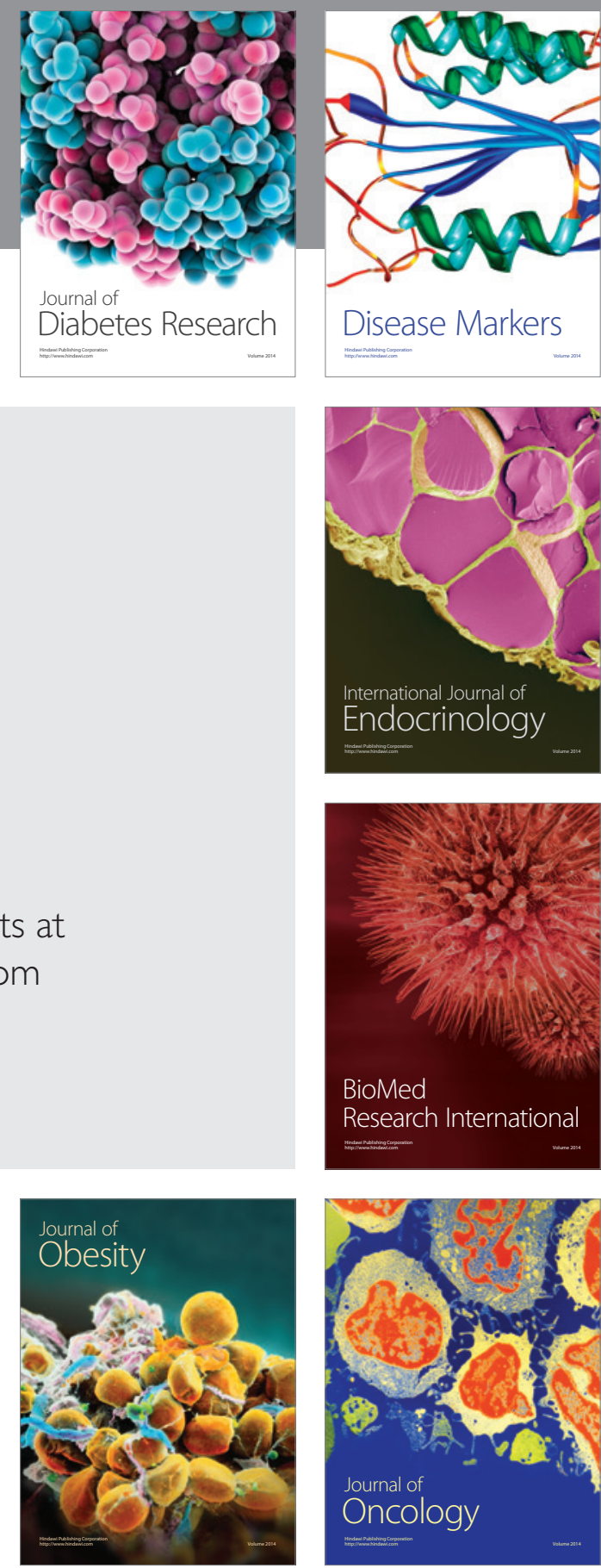

Disease Markers
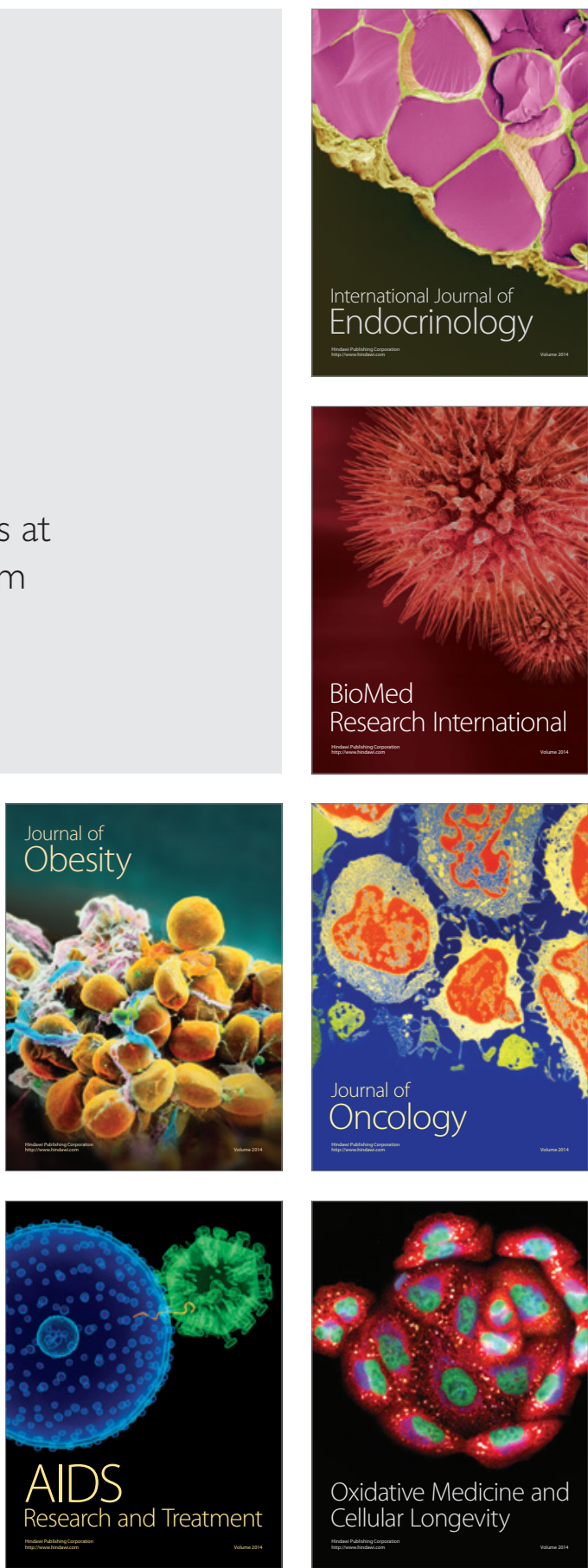